\title{
Pengaruh Frekuensi Vibrasi terhadap Penyembuhan Luka Diabetes
}

\author{
Yunita Sari $^{1}$, Eman Sutrisna ${ }^{2}$, Hartono ${ }^{3}$ \\ ${ }^{1}$ Jurusan Keperawatan, Universitas Jenderal Soedirman, Purwokerto, ${ }^{2}$ Jurusan Kedokteran, Universitas \\ Jenderal Soedirman, Purwokerto, ${ }^{3}$ Jurusan Fisika, Universitas Jenderal Soedirman, Purwokerto \\ Email :yunita-tky@umin.ac.jp/sasa.yunita@gmail.com
}

\begin{abstract}
Abstrak
Penelitian menyatakan bahwa vibrasi $47 \mathrm{~Hz}$ dapat meningkatkan penyembuhan luka diabetes. Namun sampai saat ini belum diketahui apakah frekuensi dibawah dan diatas $47 \mathrm{~Hz}$ dapat meningkatkan penyembuhan luka diabetes. Oleh karena itu, tujuan dari penelitian ini adalah untuk mengetahui efek frekuensi vibrasi yang berbeda terhadap penyembuhan luka diabetes. Desain penelitian eksperimen ini melibatkan 5 kelompok tikus putih; kelompok yang mendapatkan vibrasi $40 \mathrm{~Hz}$ (frekuensi rendah), kelompok $106 \mathrm{~Hz}$ (frekuensi menengah), kelompok $200 \mathrm{~Hz}$ (frekuensi tinggi), kelompok $300 \mathrm{~Hz}$ (frekuensi sangat tinggi), dan kelompok kontrol (tanpa vibrasi). Induksi diabetes dilakukan dengan Alloxan Monohidrat. Vibrasi diberikan selama 10 menit. Status luka didasarkan pada jaringan nekrotik, ukuran luka, inflamasi, dan reepitelisasi. Analisis histologi dilakukan dengan pewarnaan Hematoksilin dan Eosin. Ukuran luka dianalisis dengan uji ANOVA, diikuti oleh tes Tukey. Hasil penelitian menunjukkan bahwa jaringan nekrotik dan intensitas inflamasi paling sedikit pada kelompok $40 \mathrm{~Hz}$, dan paling banyak pada kelompok $300 \mathrm{~Hz}$. Reepitelisasi paling baik pada kelompok $40 \mathrm{~Hz}$, dan paling rusak pada $300 \mathrm{~Hz}$. Ukuran luka di kelompok $40 \mathrm{~Hz}$ secara signifikan lebih kecil dibandingkan dengan kelompok lain $(\mathrm{p}<0.05)$. Hasil penelitian ini menunjukkan bahwa vibrasi frekuensi rendah dapat mempercepat penyembuhan luka diabetes, sebaliknya, vibrasi frekuensi tinggi dapat merusak atau memperparah jaringan luka.
\end{abstract}

Kata kunci : Diabetes, penyembuhan, luka, terapi komplementer, vibrasi.

\section{The Provision of Different Vibration Frequency to Accelerate Diabetic Wound Healing}

\begin{abstract}
Studies have revealed that diabetic wound healing can be accelerated using the vibration therapy of $47 \mathrm{~Hz}$. However, no strong evidence compelled the use of different vibration rates. Thus, this experimental study aimed to examine the effect of different vibration frequencies towards diabetic wound healing. Five groups of white rats were injected using Alloxan Monohydrate within ten minutes before the vibration therapy. The dosage was given categorized as $40 \mathrm{~Hz}$ (low), $106 \mathrm{~Hz}$ (moderate), $200 \mathrm{~Hz}$ (high) and $300 \mathrm{~Hz}$ (very high). Control group was created without given vibration therapy. Wound status was evaluated using the presence of necrotic tissues, size, inflammation, and reepithelization where Hematoxicilin and Eosin color-based were used to analyse the histological presentation. Using ANOVA and Tukey test, it was found that the necrotic tissues and the intended inflammation have less developed among low vibration group compared to others. Reepithelization and wound size reduction most experienced by the lower group, but the worst damaged occupied by the highest vibration group. It is suggested that lower vibration frequency enabled to accelerate the wound care healing, but a high-frequency rate can disturb or damage the injured tissues.
\end{abstract}

Keywords: Complementary therapy, diabetes mellitus, wound healing. 
Yunita Sari: Pengaruh Frekuensi Vibrasi terhadap Penyembuhan Luka Diabetes

\section{Pendahuluan}

Diabetes Melitus (DM) saat ini merupakan ancaman yang serius bagi kesehatan manusia di dunia. International Diabetic Federation (IDF) (2015) menyatakan prevalensi DM di dunia pada tahun 2014 adalah sekitar 387 juta, dan diperkirakan akan menjadi 592 juta pada tahun 2035. Jumlah penderita DM juga mengalami peningkatan yang drastis di Indonesia, yaitu 8,4 juta jiwa pada tahun 2000, dan menjadi lebih dari 6,9 juta jiwa pada tahun 2016 (Sicree, Shaw, \& Zimmet, 2016). Diprediksi pada tahun 2030, Indonesia akan menduduki peringkat ke 6 negara dengan jumlah penderita DM terbesar di dunia, yaitu berjumlah 12 juta jiwa (Sicree, Shaw, dan Zimmet, 2016).

Salah satu komplikasi yang paling sering terjadi pada pasien DM adalah luka diabetes. Luka diabetes adalah penyebab utama dari amputasi ekstremitas bawah pada penderita DM (American Podiatric Medical Association, 2016). Bowker dan Pfeifer (2008) menyatakan bahwa pasien DM memiliki risiko amputasi sebesar 15-40 kali lipat bila dibandingkan dengan pasien bukan DM. Di Indonesia, 30 \% dari penderita DM pernah mengalami amputasi kaki karena luka kaki diabetes (Waspadji, 2006).

Banyak terapi dilakukan untuk meningkatkan penyembuhan luka diabetes, namun terapi-terapi ini sering gagal, terutama pada luka yang mengalami iskemia. Berdasarkan penelitian terdahulu, kegagalan penyembuhan luka kebanyakan disebabkan karena aliran darah yang kurang di daerah luka. Aliran darah yang berkurang akan menyebabkan penurunan angiogenesis. Proses angiogenesis yang terganggu akan menyebabkan gangguan pada fase proliferasi (White, Haidekker, Stevens, \& Frangos, 2004). Oleh karena itu, luka diabetes memerlukan terapi yang dapat meningkatkan aliran darah ke area luka.

Beberapa dekade terakhir, vibrasi frekuensi rendah telah terbukti dapat meningkatkan aliran darah, dan banyak digunakan untuk tujuan kesehatan.Penelitian Nakagami et al. (2007) menunjukkan bahwa vibrasi $47 \mathrm{~Hz}$ dapat menginduksi vasodilatasi dan meningkatkan aliran darah di kulit.
Penelitian-penelitian lain juga menyatakan bahwa vibrasi dengan frekuensi $50 \mathrm{~Hz}$ dapat meningkatkan aliran darah (MaloneyHinds, Petrofsky \& Zimmtererman, 2008). Penelitian-penelitian terdahulu juga menyatakan bahwa vibrasi dibawah $50 \mathrm{~Hz}$ dapat meningkatkan aliran darah kaki pada dewasa muda dan wanita perimenopouse (Kerschan et al., 2001; Lohman, Petrofsky, Schwab, \& Thrope, 2007; Lythgo, Eser, de Groot, \& Galea, 2009; Stewart, Karman, Montgomery, \& McLeod, 2005), peningkatan masa dan kekuatan tulang (Bosco et al., 1999; Wilcock, Whatman, Harris, \& Keogh, 2009). Apabila diberikan pada fruekensi rendah, vibrasi dapat menurunkan risiko fraktur tulang, penurunan gangguan otot, peningkatan kekuatan otot, perbaikan aliran cairan kaki, peningkatan proliferasi kondrosit dan lain-lain (Gusi, Raimundo, \& Leal, 2006; Kaupp \& Waldman, 2008; Roelants, Delecluse, Goris, \& Verschueren, 2004).

Penelitian sebelumnya juga menyatakan bahwa vibrasi $47 \mathrm{~Hz}$ juga dapat mempercepat penyembuhan luka, yaitu pada luka dekubitus stadium I (Arashi et al., 2010), luka dekubitus tipe injuri jaringan dalam (Sari et al., 2015a), luka dekubitus stadium 2. Lebih lanjut, Sari et al. (2015b) menemukan bahwa vibrasi dapat menurunkan hipoksia dan aktivasi MMP-2 dan MMP-9 pada luka. Turunnya kadar MMP 2 \& 9 dapat mempercepat penyembuhan luka karena kadar MMP-2 dan MMP-9 yang berlebihan dapat merusak jaringan kolagen. Penelitian lain oleh Syabariyah dan Nurahmah (2015) menyatakan bahwa vibrasi frekuensi $47 \mathrm{~Hz}$ dapat mempercepat penutupan luka diabetes pada subyek manusia. Namun sayangnya penelitian-penelitian diatas hanya menguji efek vibrasi pada frekuensi $47 \mathrm{~Hz}$, dan tidak meneliti efek vibrasi dibawah 47 $\mathrm{Hz}$ dan diatas $47 \mathrm{~Hz}$, sehingga sampai saat ini tidak diketahui apakah frekuensi dibawah $47 \mathrm{~Hz}$ dan diatas $47 \mathrm{~Hz}$ dapat meningkatkan penyembuhan luka diabetes, dan apakah aman untuk diaplikasikan pada luka diabetes. Oleh karena itu tujuan dari penelitian ini adalah untuk mengetahui rentang frekuensi vibrasi yang dapat mempercepat penyembuhan luka diabetes, serta untuk mengetahui efek vibrasi frekuensi rendah, menengah dan tinggi terhadap penyembuhan luka diabetes. 
Yunita Sari: Pengaruh Frekuensi Vibrasi terhadap Penyembuhan Luka Diabetes

\section{Metode Penelitian}

Desain penelitian pada penelitian ini adalah penelitian eksperimen dengan pendekatan post test only with control group design. Hewan coba, pada sampel yang digunakan adalah tikus putih Wistar jantan usia sekitar 12 minggu dengan kisaran berat badan 250300 gram. Besar sampel ditentukan berdasar rumus Federer untuk subyek hewan, yaitu $(\mathrm{n}-1)(\mathrm{t}-1) \geq 15$, dimana $\mathrm{n}$ adalah jumlah sampel, $\mathrm{t}$ adalah jumlah kelompok (Federer, 1991). Hasil perhitungan menunjukkan bahwa jumlah sampel minimal adalah 5 ekor tikus putih/kelompok. Penelitian ini telah mendapatkan ijin dari komisi etik penelitian untuk subyek hewan dari komisi etik Fakultas Kedokteran Universitas Jendral Soedirman, dengan nomor surat etik adalah 050/KEPK/ III/2015. Tikus dikelompokkan secara acak menjadi 5 kelompok yaitu kelompok kontrol (hanya menerima perawatan standar), kelompok vibrasi $40 \mathrm{~Hz}$ (perawatan standar dan vibrasi $40 \mathrm{~Hz}$ ), kelompok vibrasi 106 hz (perawatan standar dan vibrasi $106 \mathrm{~Hz}$ ), kelompok vibrasi $200 \mathrm{~Hz}$ (perawatan standar dan vibrasi $200 \mathrm{~Hz}$ ), dan kelompok vibrasi $300 \mathrm{hz}$ (perawatan standar dan vibrasi 300 $\mathrm{Hz}$ ).

Induksi tikus putih yang mengalami diabetes dilakukan dengan cara tikus putih diadaptasikan selama satu minggu dengan pemberian makanan standar dan air minum secara ad libitum. Tikus diinduksi aloksan dosis tunggal $120 \mathrm{mg} / \mathrm{kg} \mathrm{BB}$ tikus, intraperitoneal (Sari, Saryono, Purnawan, \& Hartono, 2014). Untuk mengetahui apakah tikus putih sudah mengalami diabetes, kadar glukosa darah tikus percobaan diukur menggunakan alat Blood Glucose Test Meter. Ekor tikus dibersihkan dengan menggunakan alkohol 70\%, kemudian selanjutnya ujung ekor ditusuk dengan jarum kecil (syringe 1 cc). Darah yang keluar kemudian disentuhkan pada strip glukometer. Rata-rata hasil pengukuran glukosa darah 7 hari setelah induksi alloxan monohidrat adalah $275 \mathrm{mg} /$ dl.

Perlukaan yang dilakukan pada tikus putih sebelum dilakukan perlukaan, bulu di sekitar punggung dicukur, kemudian tikus putih diadaptasikan selama satu hari, baru kemudian dilukai. Cara perlukaan adalah berdasarkan atas penelitian sebelumnya yaitu dengan menggunakan gunting sampai lapisan kulit paniculus carnosus (Sari, Saryono, Purnawan, \& Hartono, 2014). Kemudian tikus diberi injeksi ketamile $(25-30 \mathrm{mg} / \mathrm{kg} \mathrm{BB}$ tikus) untuk anestesi. Luka dengan diameter $1 \mathrm{~cm}$ dilakukan di daerah perut bagian kanan (flank region) dengan menggunakan gunting yang steril. Kedalaman luka adalah sampai pada lapisan paniculus carnosus. Luka kemudian ditutup dengan pembalut luka film transparan.

Terapi vibrasi pada penelitian ini menggunakan kasur vibrasi diciptakan oleh peneliti (Sari, Sutrisna, \& Hartono, 2015a). Tempat tidur yang bisa bergetar dibuat dengan menggunakan motor getar. Gambar dari kasur vibrasi dapat dilihat di gambar 1. Secara singkat, kasur vibrasi dibuat dengan cara meletakan 3 motor getar pada kasur. Frekuensi vibrasi diukur dengan menggunakan vibration analyzer. Frekuensi vibrasi dapat diatur dengan merubah kecepatan dari motor getar. Terapi vibrasi diberikan dengan cara menidurkan tikus pada kasur getar. Vibrasi diberikan selama 10 menit.

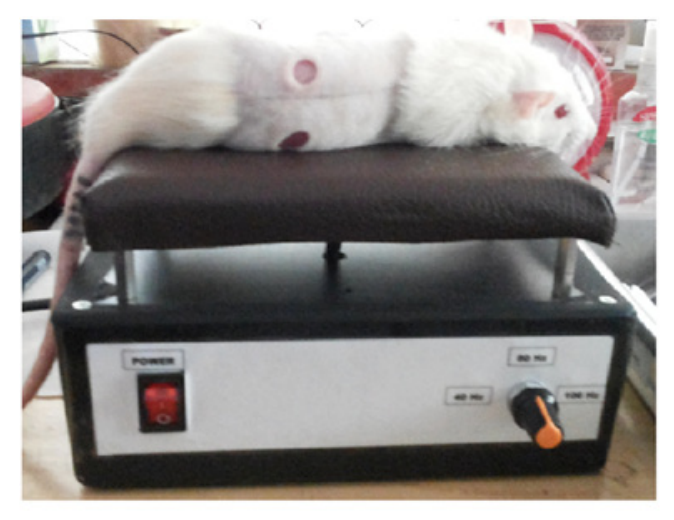

Gambar 1 Kasur getar (Sari, Sutrisna, \& Hartono., 2015a)

\section{Pengukuran/Pengumpulan Data}

Pewarnaan jaringan luka dilakukan dengan cara jaringan kulit pada tikus diambil pada hari ke-8. Setelah tikus dibunuh, jaringan difiksasi dengan $10 \%$ formalin. Kemudian dilakukan dehidrasi pada jaringan dengan alkohol dan xylene, kemudian dibungkus dengan paraffin. Jaringan kulit akan dipotong dengan mikrotom dengan ketebalan $5-\mu \mathrm{m}$. Jaringan kemudian dideparafinisasi di xylene, 
Yunita Sari: Pengaruh Frekuensi Vibrasi terhadap Penyembuhan Luka Diabetes

rehidrasi di etanol, dan dicuci di air steril. Jaringan kemudian diberi pewarnaan dengan hematoksilin dan eosin untuk menentukan inflamasi dan nekrosis. Setelah itu, akan diobservasi dengan mikroskop dengan perbesaran 40 kali dan 100 kali. Sebelum diambil jaringannya, tikus akan dibunuh terlebih dahulu dengan menggunakan overdosis ketamile. Sisa jaringan akan dikubur.

Proses inflamasi ditandai dengan adanya sel-sel peradangan. Sel-sel peradangan ini akan memberikan warna biru keunguan dengan pewarnaan Hematoksilin dan Eosin. Luas luka diukur dengan menggunakan software image analysis, yaitu Image $J$. (Schneider et al, 2012). Kecepatan penutupan luka antar kelompok diperbandingkan dalam bentuk rasio luas luka. Rasio luas luka adalah nilai relatif yang diperoleh dengan cara membandingkan luas luka pada hari ke-n dengan luas luka hari sebelumnya, atau n-1 (rasio luas luka) ( Ueda et al, 2010).

Reepitelisasi ditandai dengan munculnya lapisan epitel baru pada epidermis. Reepitelisasi diamati dengan menggunakan mikroskop cahaya. Hasil pengamatan dideskripsikan secara kualitatif. Data luas luka dianalisis menggunakan uji ANOVA, diikuti oleh tes Tukey. Nilai $\mathrm{p}<0,05$ dianggap signifikan.

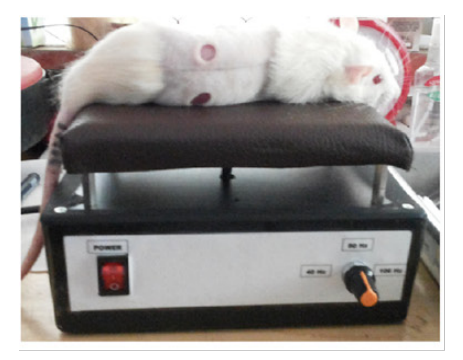

\section{Hasil Penelitian}

Hasil penelitian menunjukkan pada gambar 2 yaitu perbedaan makroskopis antara kelompok yang diberi vibrasi $40 \mathrm{~Hz}, 106$ $\mathrm{Hz}, 200 \mathrm{~Hz}$, dan $300 \mathrm{~Hz}$ serta kelompok kontrol. Pada hari ke 0, penampakan semua luka menunjukkan gambaran makroskopis yang sama. Mulai hari kedua, luka pada kelompok vibrasi $300 \mathrm{~Hz}$ mulai terdapat jaringan nekrotik tipis pada dasar luka, sedangkan pada kelompok 40, 106, dan 200 $\mathrm{Hz}$, dasar luka terisi oleh jaringan granulasi yang merah. Pada hari ketiga, jaringan nekrotik semakin tebal pada kelompok vibrasi 300 Hz. Jaringan nekrotik juga mulai terlihat dikelompok $200 \mathrm{~Hz}$ pada hari ketiga. Sebaliknya, jaringan nekrotik pada hari ketiga belum terlihat pada kelompok $40 \mathrm{~Hz}, 106$ $\mathrm{Hz}$, dan kontrol. Pada hari kelima, jaringan nekrotik semakin tebal di kelompok $200 \mathrm{~Hz}$ dan $300 \mathrm{~Hz}$ dibandingkan hari sebelumnya. Pada hari kelima, jaringan nekrotik mulai muncul pada kelompok kontrol. Pada hari keenam dan ketujuh, jaringan nekrotik masih tebal pada kelompok $200 \mathrm{~Hz}$ dan $300 \mathrm{~Hz}$. Jaringan nekrotik pada kelompok kontrol juga makin menebal. Pada hari ke 0 sampai ke 8, dasar luka pada kelompok $40 \mathrm{~Hz}$ dan $106 \mathrm{~Hz}$ terisi oleh jaringan granulasi dan ukuran luka semakin mengecil. Pada hari ke

Gambar 2 Hasil makroskopis antara kelompok $40 \mathrm{~Hz}, 106 \mathrm{~Hz}, 200 \mathrm{~Hz}, 300 \mathrm{~Hz}$, dan kontrol. (Ukuran bar adalah $1 \mathrm{~cm}$ ) 
delapan, luka pada kelompok $40 \mathrm{~Hz}$ dan 106 $\mathrm{Hz}$ hampir menutup. Sebaliknya, jaringan nekrotik pada kelompok $200 \mathrm{~Hz}$ dan $300 \mathrm{~Hz}$ dan kontrol masih terlihat tebal.

Perbandingan luas luka diantara lima kelompok dapat dilihat pada gambar 3. Pada hari ke 6,7, dan 8 luas luka pada kelompok $40 \mathrm{~Hz}$ secara signifikan lebih kecil bila dibandingkan dengan kelompok kontrol $(\mathrm{p}$ $<0,01$ pada hari ke $6, p<0,05$ pada hari ke 7 , dan $\mathrm{p}<0,01$ pada hari ke 8 ), kelompok 200 $\mathrm{Hz}(\mathrm{p}<0,01$ pada hari ke $6, \mathrm{p}<0,01$ pada hari ke 7, dan $\mathrm{p}<0,01$ pada hari ke 8) ), kelompok $300 \mathrm{~Hz}(\mathrm{p}<0,01$ pada hari ke 6, $\mathrm{p}<0,01$ pada hari ke 7, dan $p<0,01$ pada hari ke 8). Pada hari ke 6 dan 7, luas luka pada kelompok $40 \mathrm{~Hz}$ juga secara signifikan lebih kecil (p $<0,05)$ daripada kelompok $106 \mathrm{~Hz}$.

Gambar 4 adalah gambaran mikroskopis pada epidermis dengan menggunakan pewarnaan Hematoksilin dan Eosin. Bagian atas adalah gambaran mikroskopis pada kelompok $40 \mathrm{~Hz}, 106 \mathrm{~Hz}$, dan $200 \mathrm{~Hz}$, sedangkan bagian bawah adalah kelompok $300 \mathrm{~Hz}$ dan kontrol. Intensitas inflamasi dapat dilihat melalui gambaran warna ungu pada pewarnaan hematoksilin dan Eosin. Intensitas inflamasi pada kelompok $40 \mathrm{~Hz}$ adalah yang paling sedikit dibanding dengan kelompok-kelompok lain. Ketika intensitas inflamasi pada kelompok kontrol, $200 \mathrm{~Hz}$ dan $300 \mathrm{~Hz}$ diperbandingkan, intensitas inflamasi pada kelompok kontrol lebih sedikit bila dibandingkan kelompok $200 \mathrm{~Hz}$ dan $300 \mathrm{~Hz}$. Intensitas inflamasi terbesar terlihat pada kelompok $300 \mathrm{~Hz}$.

Gambar 5 merupakan gambaran mikroskopis dari dermis antara kelompok $40 \mathrm{~Hz}, 40 \mathrm{~Hz}, 106 \mathrm{~Hz}, 200 \mathrm{~Hz}, 300 \mathrm{~Hz}$, dan kontrol. Intensitas inflamasi terendah adalah pada kelompok $40 \mathrm{~Hz}$. Inflamasi pada kelompok kontrol lebih sedikit bila

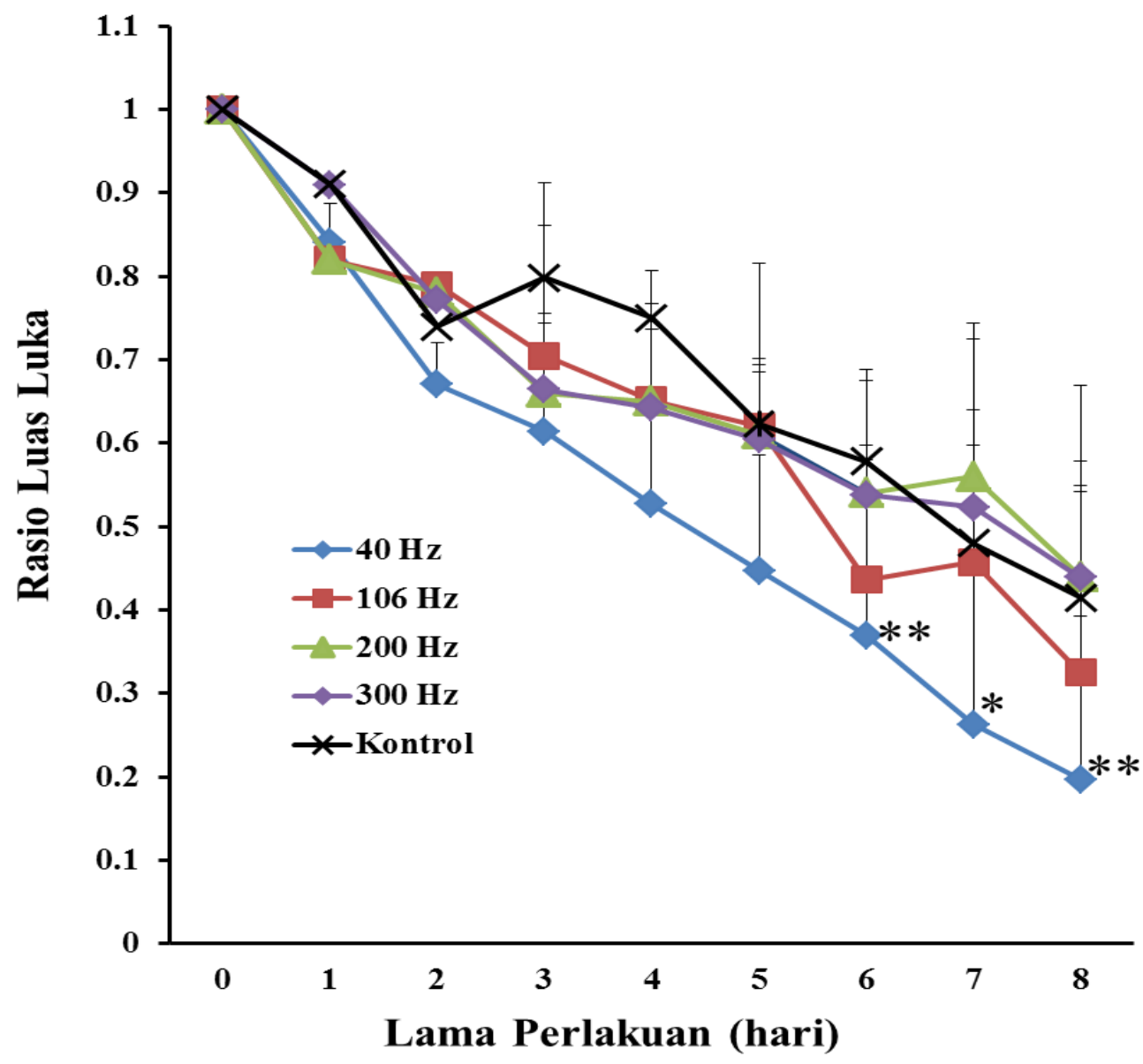

Gambar 3 Perbandingan ukuran antara kelompok $40 \mathrm{~Hz}, 106 \mathrm{~Hz}, 200 \mathrm{~Hz}, 300 \mathrm{~Hz}$, dan kontrol.(* adalah $\mathrm{p}<0,05 ; * *$ adalah $\mathrm{p}<0,01$ ) 


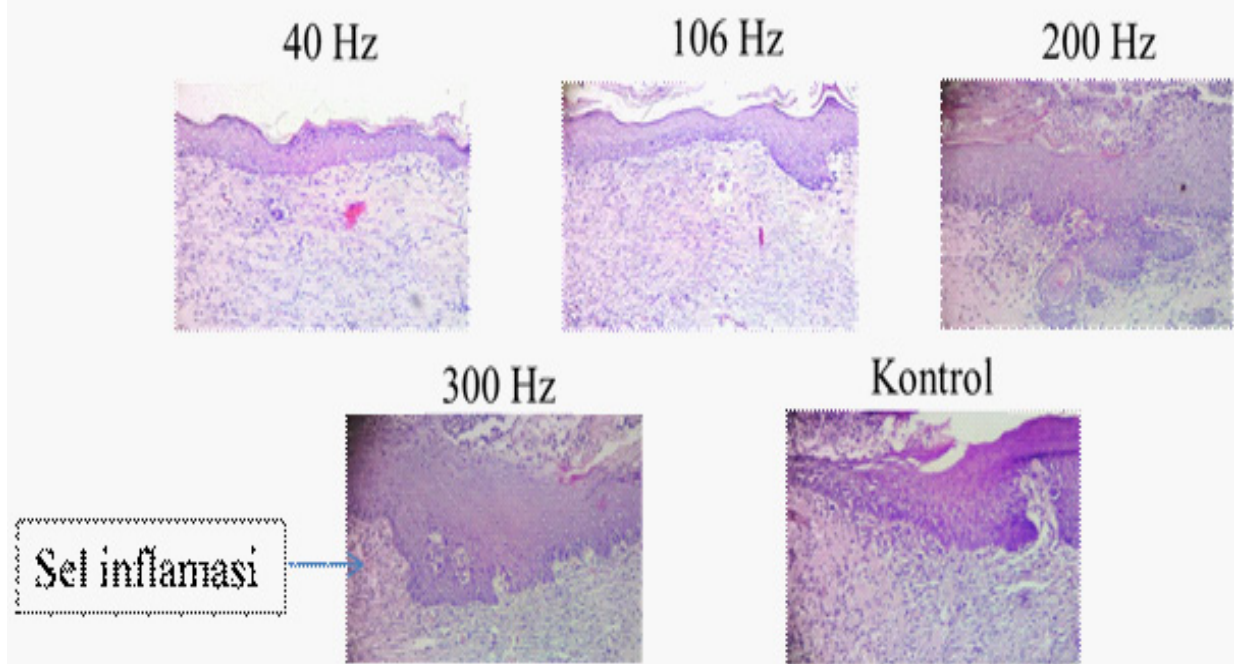

Gambar 4 Perbandingan gambar inflamasi pada epidermis antara $40 \mathrm{~Hz}, 106 \mathrm{~Hz}, 200 \mathrm{~Hz}, 300 \mathrm{~Hz}$, dan kontrol (perbesaran 100X)
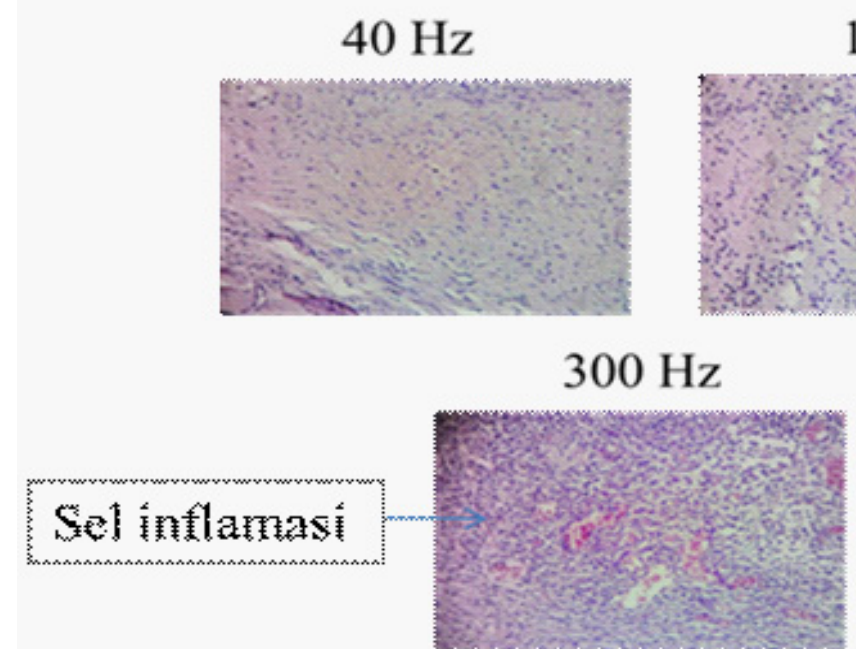

$106 \mathrm{~Hz}$

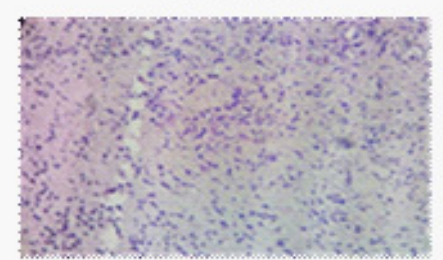

$200 \mathrm{~Hz}$

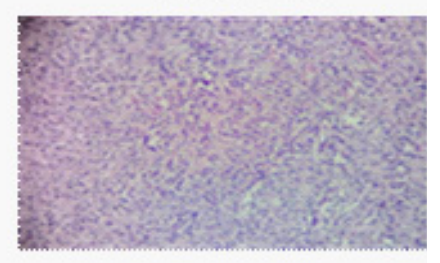

Kontrol

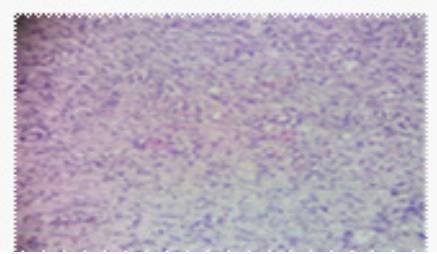

Gambar 5 Perbandingan inflamasi pada dermis antara $40 \mathrm{~Hz}, 106 \mathrm{~Hz}, 200 \mathrm{~Hz}, 300 \mathrm{~Hz}$, dan kontrol (Perbesaran 100X)

dibandingkan pada kelompok $200 \mathrm{~Hz}$. Intensitas inflamasi terbesar terlihat di kelompok $300 \mathrm{~Hz}$.

Gambar 6 menunjukkan gambaran reepitelisasi pada kelompok $40 \mathrm{~Hz}, 106$ $\mathrm{Hz}, 200 \mathrm{~Hz}, 300 \mathrm{~Hz}$, dan kontrol dengan menggunakan pewarnaan Hematoksilin dan Eosin (reepitelisasi ditandai dengan adanya jaringan epitel baru pada epidermis). Dari gambar 6 terlihat bahwa reepitelisasi telah terjadi pada semua kelompok, namun reepitelisasi pada kelompok $40 \mathrm{~Hz}$ lebih advance bila dibandingkan dengan kelompok-kelompok lain. Pada kelompok $40 \mathrm{~Hz}$, sel inflamasi juga sangat sedikit pada epidermis yang baru. Gambaran reepitelisasi pada kelompok $106 \mathrm{~Hz}$ hampir mirip dengan kelompok $40 \mathrm{~Hz}$, namun pada kelompok $106 \mathrm{~Hz}$ masih terdapat banyak sel inflamasi pada epidermis yang baru. Pada kelompok $40 \mathrm{~Hz}$ dan $106 \mathrm{~Hz}$, di atas epidermis yang baru tidak terdapat jaringan nekrotik. Sebaliknya, pada kelompok $200 \mathrm{~Hz}, 300$ $\mathrm{Hz}$ dan kontrol, di atas epidermis yang baru terdapat jaringan nekrotik (ditandai dengan sel inflamasi yang banyak) yang menutupi 


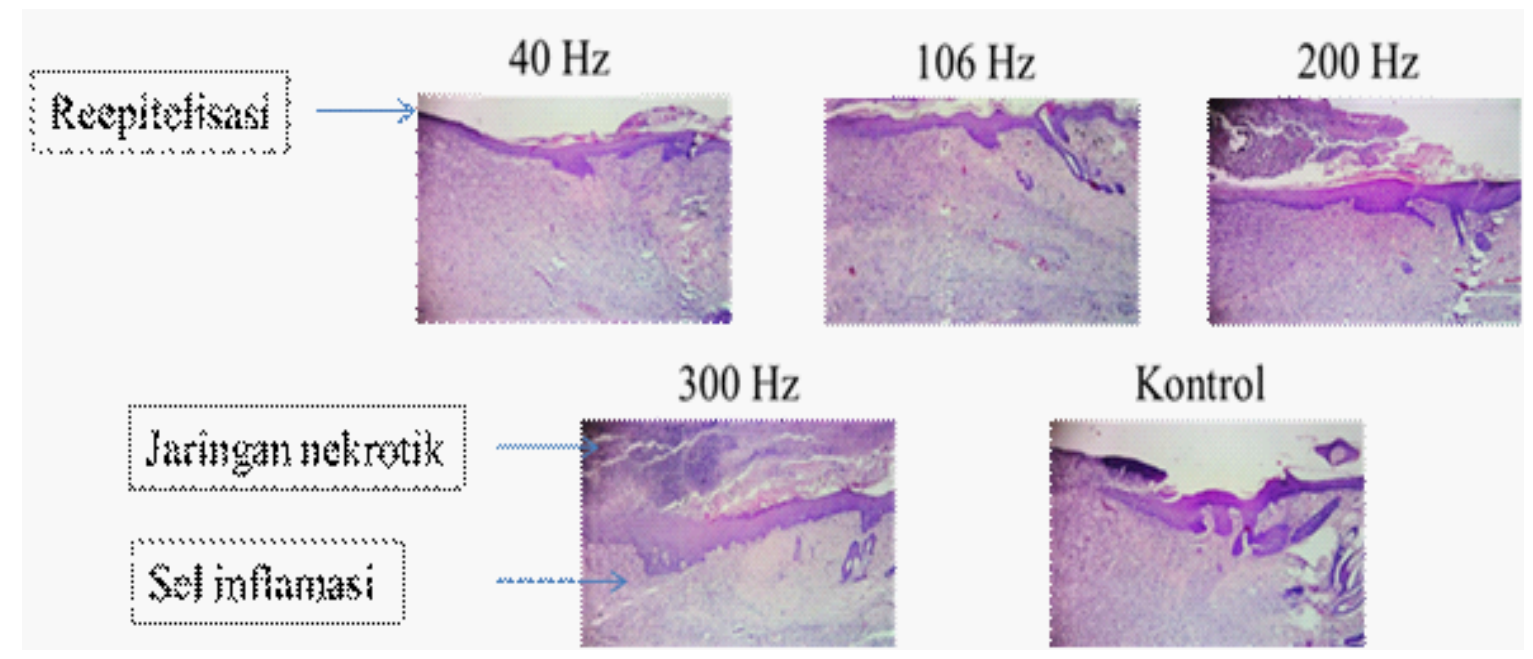

Gambar 6 Perbandingan reepitelialisasi antara $40 \mathrm{~Hz}, 106 \mathrm{~Hz}, 200 \mathrm{~Hz}, 300 \mathrm{~Hz}$, dan kontrol (Perbesaran 40X)

epidermis. Pada kelompok kontrol, jaringan nekrotik di atas epidermis lebih sedikit bila dibandingkan pada kelompok $200 \mathrm{~Hz}$ dan $300 \mathrm{~Hz}$. Ketika kelompok $200 \mathrm{~Hz}$ dan 300 $\mathrm{Hz}$ diperbandingkan, jaringan nekrotik di atas epidermis pada kelompok $200 \mathrm{~Hz}$ lebih sedikit dibandingkan dengan kelompok 300 $\mathrm{Hz}$.

\section{Pembahasan}

Penelitian ini merupakan penelitian pertama dalam literatur yang meneliti tentang efek vibrasi fruekensi rendah, menengah, dan tinggi dalam meningkatkan penyembuhan luka diabetes. Dalam penelitian ini, Kami mendapatkan hasil bahwa vibrasi frekuensi rendah dapat meningkatkan penyembuhan luka diabetes pada hewan coba. Kami juga memperoleh hasil bahwa vibrasi fruekensi tinggi tidak dapat mempercepat penyembuhan luka diabetes, bahkan efeknya dapat merusak jaringan luka.

Berdasarkan atas penelitian terdahulu, vibrasi dapat meningkatkan aliran darah pada luka, sehingga dapat mengurangi hipoksia jaringan (Sari et al, 2015b). Nakagami et al. (2007) dan Ichioka et al. (2011) memberikan aplikasi vibrasi sebesar $47 \mathrm{~Hz}$ pada telinga mencit. Setelah pemberian vibrasi, terjadi vasodilatasi pembuluh darah yang diukur secara real time dengan menggunakan intravital videomicroskope. Hasil penelitian dari Sari et al.(2015b) juga menunjukkan bahwa setelah pemberian vibrasi dengan frekuensi $47 \mathrm{~Hz}$ selama 7 hari, tingkat hipoksia jaringan menurun bila dibandingkan dengan jaringan yang tidak mendapat vibrasi. Menurut Nakagami et al. (2007) vibrasi $47 \mathrm{~Hz}$ dapat mengakibatkan shear stress sehingga akan mengakibatkan terjadinya peningkatan NO (Nitric oxide) yang lebih lanjut akan mengakibatkan terjadinya vasodilatasi pembuluh darah. Lebih lanjut, dijelaskan juga bahwa vibrasi dapat menyebabkan stimulasi pelepasan substansi $\mathrm{P}$ dan peptide terkait gene kalsitonin yang dapat menyebabkan terjadinya vasodilatasi pembuluh darah.

Dalam penelitian ini, vibrasi $40 \mathrm{~Hz}$ (frekuensi rendah), dan vibrasi $106 \mathrm{~Hz}$ (frekuensi sedang) dapat meningkatkan penyembuhan luka diabetes, namun gambaran makroskopis dan mikroskopis menunjukkan bahwa vibrasi $40 \mathrm{~Hz}$ (frekuensi rendah) lebih dapat menurunkan inflamasi dan jaringan nekrotik dibanding vibrasi $106 \mathrm{~Hz}$ (frekuensi sedang). Gambaran lapisan epidermis yang baru juga lebih baik pada kelompok vibrasi frekuensi rendah dibanding frekuensi tinggi.

Pada penelitian terdahulu, Syabariyah dan Nurahmah (2015) menyatakan bahwa vibrasi $47 \mathrm{~Hz}$ dapat mempercepat penyembuhan luka diabetes. Menurut hasil penelitian kami, 
Yunita sari : Pengaruh Frekuensi Vibrasi terhadap Penyembuhan Luka Diabetes

ternyata vibrasi dibawah $47 \mathrm{~Hz}$ juga dapat mempercepat penyembuhan luka diabetes. Hasil lain dari penelitian ini yang belum ada dalam penelitian terdahulu adalah vibrasi frekuensi tinggi $(200 \mathrm{~Hz}$ keatas) ternyata dapat merusak jaringan luka diabetes. Hal ini kemungkinan disebabkan karena vibrasi fruekensi di atas $125 \mathrm{~Hz}$ dapat mengakibatkan vasokonstriksi pembuluh darah karena adanya peningkatan ROS dan penurunan NO (Hughes et al, 2009).

Hasil penelitian ini menunjukkan bahwa vibrasi frekuensi rendah dapat meningkatkan proses reepitelisasi. Dalam fase penyembuhan luka, proses reepitelisasi akan melibatkan keseimbangan antara enzim pendegradasi kolagen, yaitu MMP dan enzim penghambat degradasi, yaitu Tissue inhibitor of metalloproteinase. Pada luka diabetes, terdapat kelebihan MMP, sehingga proses reepitelisasi terganggu. Penelitian terdahulu oleh peneliti menemukan bahwa vibrasi dapat menurunkan aktivasi MMP-2 dan MMP-9 pada luka dekubitus, sehingga proses reepitelisasi berjalan dengan baik (Sari et $a l, 2015 b)$. Dalam penelitian ini, epidermis terbentuk dengan sempurna pada hari ke 8 pada kelompok vibrasi frekuensi rendah, hal ini kemungkinan besar disebabkan karena vibrasi frekuensi rendah juga menurunkan aktivasi MMP-2 dan MMP-9 pada luka diabetes. Pengukuran aktivasi MMP-2 dan MMP-9 dengan zymografi perlu dilakukan pada penelitian yang akan datang untuk mengkonfirmasi mekanisme ini.

Hasil dari penelitian ini membawa ilmu yang baru dalam literatur, yaitu bahwa vibrasi $40 \mathrm{~Hz}$ dapat mempercepat reepitelisasi dan menurunkan inflamasi, namun vibrasi fruekensi tinggi $(200 \mathrm{~Hz}$ keatas) dapat meningkatkan inflamasi dan merusak reepitelisasi. Dalam penelitian ini didapatkan data bahwa pemberian vibrasi fruekensi rendah tidak mengakibatkan terjadinya efek samping. Seratus persen hewan coba yang digunakan dalam penelitian ini tidak ada yang mati selama pemberian terapi vibrasi. Data makroskopik dan mikroskopik juga membuktikan bahwa terapi vibrasi ini dapat menurunkan inflamasi dan jumlah jaringan nekrotik. Hal ini menunjukkan bahwa terapi vibrasi dengan menggunakan kasur vibrasi ini memungkinkan untuk diujicobakan pada luka DM pada manusia di masa depan untuk mengetahui efektifitasnya pada penyembuhan luka diabetes pada manusia.

\section{Simpulan}

Penelitian ini adalah merupakan penelitian pertama dalam literatur yang meneliti tentang efek vibrasi frekuensi rendah, menengah dan tinggi terhadap luka diabetes. Berdasarkan hasil penelitian ini, vibrasi $40 \mathrm{~Hz}$ (frekuensi rendah) dan $106 \mathrm{~Hz}$ (frekuensi menengah) dapat meningkatkan penyembuhan luka diabetes. Namun efek vibrasi $40 \mathrm{~Hz}$ pada penyembuhan luka diabetes lebih baik bila dibandingkan efek dari vibrasi $106 \mathrm{~Hz}$. Hasil mikroskopis dan makroskopis menunjukkan bahwa vibrasi dengan frekuensi $40 \mathrm{~Hz}$ dapat menurunkan inflamasi, meningkatkan jaringan granulasi, dan mempercepat reepitelisasi. Sebaliknya, vibrasi fruekensi tinggi dapat mengakibatkan kerusakan jaringan. Kedepannya, vibrasi $40 \mathrm{~Hz}$ perlu diujicobakan pada pasien dengan luka diabetes pada subyek manusia.

\section{Daftar Pustaka}

American Podiatric Medical Association. (2016). What is a Diabetic Foot Ulcer?. Retrieved from http://www.apma.org/Learn/ FootHealth.cfm?ItemNumber $=981$.

Arashi, M., Sugama, J., Sanada, H., Konya, C., Okuwa, M., Nakagami, G., ... Tabata K. (2010). Vibration therapy accelerates healing of stage I pressure ulcers in older adult patients. Advances in skin dan wound care, 23(7), 321-327.

Bosco C, Colli R, Introini E, Cardinale M, Tsarpela O, Madella A, Viru A. (1999). Adaptive responses of human skeletal muscle to vibration exposure. Clin Physiol, 19, 1837.

Bowker, J. H., \& Pfeifer, M. A. (2008). The Diabetic Foot. Philadelphia: Mosby Elsevier.

Federer W. (1991). Statistics and society: data collection and interpretation. 2nd ed. 
Yunita sari : Pengaruh Frekuensi Vibrasi terhadap Penyembuhan Luka Diabetes

New York: Marcel Dekker.

Gusi, N., Raimundo, A., \& Leal, A. (2006). Low-frequency vibratory exercise reduces the risk of bone fracture more than walking: a randomized controlled trial. $B M C$ Muskuloskeletal Disorder; 7, 92.

Hughes, J. M., Wirth, O, Krajnak, K., Miller, R., Flavahan, S., Berkowitz, D. E., ... Flavahan, N. A. (2009) Increased oxidant activity mediates vascular dysfunction in vibration injury. J Pharmacol Exp Ther, 328(1), 22330. doi: 10.1124/jpet.108.144618.

Ichioka S, Yokogawa H, Nakagami G, Sekiya N, Sanada H. (2011). In vivo analysis of skin microcirculation and the role of nitric oxide during vibration. Ostomy Wound Manage, 57(9):40-7.

International Diabetic Federation. (2015). International Working Group on Diabetic Foot.Retrieved from http://www.iwgdf.org/ index.php?option $=$ com_content\&task $=$ view \&id=33\&Itemid=48.

Kaupp, J. A., \& Waldman, S. D. (2008). Mechanical vibrations increase the proliferation of articular chondrocytes in high-density culture. Proc.ImechE, 222(1), 695-703.

Kerschan-Schindl K1, Grampp S, Henk C, Resch H, Preisinger E, Fialka-Moser V, Imhof H. (2001). Whole-body vibration exercise leads to alterations in muscle blood volume. Clin Physiol, 21, 377-82.

Lohman, E. B., Petrofsky, J. S., MaloneyHinds., Schwab, H. B., \& Thrope, D. (2007). The effect of whole body vibration on lower extremity skin blood flow in normal subjects. Med Sci Monit, 13(2).

Lythgo, N., Eser, P., de Groot, P., \& Galea, M. (2009). Whole-body vibration dosage alters leg blood flow. Clin Physiol Funct Imaging, $29,53-9$.

Maloney-Hinds., Petrofsky, J. S., \& Zimmerman, G. (2008). The effect of $30 \mathrm{~Hz}$ vs $50 \mathrm{~Hz}$ passive vibration and duration of vibration on skin blood flow in the arm. Med Sci Monit, 14(3), 112-116.

Nakagami, G., Sanada, H., Matsui, N., Kitagawa, A., Yokogawa, H., Sekiya, N., ... Shibata, M. (2007). Effect of vibration on skin blood flow in an in vivo microcirculatory model. BioScience Trends, 1(3), 161-166.

Roelants, M., Delecluse, C., Goris, M., \& Verschueren, S. (2004). Effect of 24 weeks of whole body vibration training on body composition and muscle strength in untrained females. International Journal of Sports Medicine, 25(1).

Sari, Y., Saryono., Purnawan, I., \& Hartono. (2014). Modification of breast pump as a negative pressure wound herapy for accelerating wound healing of diabetic ulcer. Jurnal Ners, 10(1), 104-111.

Sari, Y., Sutrisna, E., \& Hartono. (2015a). Low frequency vibration attenuate inflammation and improve reepithelialization of diabetic ulcer. 5th International Nursing Conference UI. September 16-18. Jakarta, Indonesia.

Sari, Y., Sanada, H., Minematsu, T., Nakagami, G., Nagase, T., Huang, L., ... Sugama, J. (2015b). Vibration inhibits deterioration in rat deep-tissue injury through HIF1-MMP axis. Wound Repair Regen, 23(3), 386-93. doi: 10.1111/wrr.12286.

Schneider CA, Rasband WS, Eliceiri KW. (2012). NIH Image to ImageJ: 25 years of image analysis. Nat Methods, 9(7):671-5.

Sicree, R., Shaw, J., \& Zimmet, P. (2016). The global burden diabetes and impaired glucose tolerance: IDF diabetes atlas fourth edition.Retrieved from https://www.idf. org/sites/default/files/Diabetes $\% 20$ and $\% 20$ Impaired\%20Glucose \%20Tolerance 1.pdf., pada 4 April 2016.

Stewart, J. M., Karman, C., Montgomery, L. D., \& McLeod, K. J. (2005). Plantar vibration improves leg fluid flow in perimenopausal women. Am J Physiol Regul Integr Comp Physiol, 288, 623-9. 
Yunita sari : Pengaruh Frekuensi Vibrasi terhadap Penyembuhan Luka Diabetes

Syabariyah, S, \& Nurachmah, E (2015). Vibration Adjuvant Wound Therapy Enhances The Healing of Diabetic Foot Ulcers: An Interim Analysis of 31 Patient. Jurnal Online STIK Muhammadiyah Pontianak. Doi: journal.stikmuhptk.ac.id/index.php/jokksmp/ article/download/76/3.

Ueda K, Akase T, Nakagami G, Nagase T, Minematsu T, Huang L, Sagara H, Ohta Y, Sanada H.(2010). A possible animal model for critical colonisation. $J$ Wound Care 19(7):295-300.

Waspadji, S. (2006). Komplikasi kronik diabetes: Mekanisme terjadinya, diagnosis dan strategi pengelolaan ilmu penyakit dalam. Fourth edition. Jakarta: FK UI.

White, C. R., Haidekker, M.A., Stevens, H. Y., \& Frangos, J. A. (2004). Extracellular signal-regulated kinase activation and endothelin-1 production in human endothelial cells exposed to vibration. $J$ Physiol, 555, $565-572$.

Wilcock, I. M., Whatman, C., Harris, N., \& Keogh, J. W. (2009). Vibration training: could it enhance the strength, power, or speed of athletes? J Strength Cond Res, 23, 593-603. 